\title{
What Causes Canadian Aboriginal Protest? Examining Resources, Opportunities and Identity, 1951-2000
}

\author{
Howard Ramos
}

\begin{abstract}
Drawing on the social movement literature, this paper tests whether or not Canadian Aboriginal protest, 1951-2000, can be explained by resource mobilization, political opportunities, or the construction of a PanAboriginal collective identity. Using regression analysis it argues that the strongest influences on protest are the founding of new organizations, federal monies, media attention, and successful resolution of land claims. The paper also concludes that differences among "status groups," and their access to resources and opportunities, inhibit broad based PanAboriginal protest.
\end{abstract}

Résumé: Cet article se base sur la discipline de mouvements sociaux pour tester si les démonstrations d'autochtones canadiens peuvent être expliquées par les théories de mobilisation de ressources, d'opportunités politiques ou d'identité collective Pan- Autochtones. En utilisant une analyse de régression, l'article maintient que les influences les plus considérables sur les démonstrations sont l'établissement de nouveaux organismes, l'aide fédéral, l'attention médiatique ainsi que la résolution favorable de disputes territoriales. L'article conclu également que des différences entre les « groupes de statuts » ainsi que dans leur accès à des ressources et opportunités ont une influence néfaste sur les démonstrations Pan-Autochtones plus étendu.

During the 1990s, Canada experienced a rise of Aboriginal contentious action. Opposition against the Meech Lake Accord, its defeat, the violent standoff at Oka, the Dudley George shooting at Ipperwash Park, or the Mi' qmak lobster crisis in the Maritimes are just some examples. ${ }^{1}$ However,

1. I would like to thank Suzanne Staggenborg, Steven Rytina, James Ron, Yoko Yoshida, Devrim Yavuz, Emma Whelan, Patrick Pearce, and the CJS editors and anonymous reviewers for their constructive comments. Thanks also go to Selom Chapman-Nyaho who assisted with some of the data collection. The research was funded by Fonds pour la Formation de Chercheurs et l'Aide à la Recherche (FCAR) and the McGill Institute for the Study of Canada. 
few scholars systematically examine why this increase in protest occurred or why it was so widespread. Instead, the vast majority of scholarship exploring Canadian Aboriginal contention focuses on a single status group or First Nation, relying on anthropological, ethnographic and historical analysis. ${ }^{2}$ Despite some notable exceptions, such as Wilkes (2004), Carroll and Ratner (1996a; 1996b), Long (1992), and Tennant (1990), large-scale studies looking at wider patterns over time and space remain rare.

This paper addresses this research gap by testing which factors influenced Canadian Aboriginal protest during the 1951-2000 period. Drawing on social movement literature, it examines whether resource mobilization, political opportunities, or the construction of a PanAboriginal collective identity account for protest. Using regression analysis, I argue its strongest influences are the founding of new organizations, federal monies allocated to Indian Affairs, media attention, and successful resolution of land claims. The paper also concludes that PanAboriginal identity poorly accounts for increased protest, because differences in legal status among Aboriginals and federal funding of organizations generate competition and divisions among them.

\section{Possible Influences}

The social movement literature offers many explanations for why people act contentiously. By this I simply mean acting and organizing outside dominant institutions, with the intention of engaging or challenging power holders. ${ }^{3}$ In recent years three perspectives have come to dominate the literature: resource mobilization, political opportunities, and collective identity. ${ }^{4}$ This is not to say

2. For example, Cardinal (1969) looks at the plight of status-Indians or First Nations mobilization; Adams (1975; 1995) examines Métis mobilization; Alfred (1995) and Pertusati (1997) look at Mohawk-Canadian relations; Gagné (1994), Jenson and Papillion (2000), Niezen (2003;1998) and Salisbury (1986) examine James Bay Cree relations with Quebec and Canada; VanWynsberghe $(2001 ; 2000)$ documents mobilization at Walpole island, Ontario; and Sanderson and Howard-Bobiwash (1997) examine the development of the Aboriginal community in Toronto.

3. Here I differ from many looking at "social movements," who add to the definition a need for sustained action. Unlike these scholars I am interested in "protest" events, whether sustained or not. This follows a distinction made by Diani (1992) who cautions against conflating the two, and is in line with other scholars tracking protest events (cf. Earl et al., 2004; Oliver and Myers, 1999; Soule et al., 1999). Likewise, empirical findings support my decision; $24 \%$ of all protests coded were held by Aboriginal individuals with no explicit link to a broader movement organization. That is, the news stories coded did not mention an organization supporting such actions. This was approximately $18 \%$ higher than the number of actions by "Traditionalists/Warriors." Thus, to accurately account for increase and decrease of Canadian Aboriginal protest, it makes sense to include such actions. A failure to do so would lead to misspecification.

4. Although earlier work on collective behavior can also account for protest, I will not engage this perspective in this paper. (see Killian, 1984; Turner and Killian, 1987) 
they are exhaustive of the area but rather provide consistent insight for why people mobilize.

The resource mobilization perspective accounts for contentious action by looking at the resources needed to organize and coordinate actions. Usually this perspective links protest to the availability of financial assets (cf. Zald and Ash, 1966; Zald and McCarthy, 1980), but also examines other types of resources, such as social or human capital and the availability of organizations (cf. Donati, 1996; McAdam, 1982). In fact, many advocates of this perspective measure the success of resource mobilization by the presence of organizations that act as hubs of interaction and assets. Proponents of this line of thought, like those looking at civil society, argue that political participation increases according to the availability of resources.

In the case of Canadian Aboriginal protest, resources include a number of different factors, such as the presence of national organizations, the availability of government funding, and human capital that can be drawn upon. This leads to my first hypothesis:

\section{H1: The greater the availability of resources, the more protest.}

However, there is debate over whether organizations mobilize people to act contentiously or instead to participate in dominant institutions. Piven and Cloward (1991), for example, caution that formal organizations get co-opted and generate greater participation in the polity, rather than contentious action against it. These concerns are echoed by a number of people who look at the role civil society plays in stable states. These researchers associate the presence of organizations and their resources with greater participation in dominant institutions rather than protest (cf. Fukuyama, 1995; Putnam, 2000). As a result, although resource mobilization may lead to contention, it may also contribute to incorporation into dominant political processes.

Another perspective that may shed light on these contradictory findings is political opportunity. It accounts for contentious action through the presence or absence of systemic opportunities. Protest is considered to be tied to openings and closings of the polity. Tarrow (1988) observed that contention usually occurs in ebbs and flows with a clustering around specific events, new resources, emerging divisions among elites, and general changes in state-civil society relations. Many find that protest is linked to both the emergence and loss of opportunities (Meyer, 2004; Meyer and Minkoff, 2004). For example, on the one hand, Minkoff (1997) finds increased action associated with opening opportunities, and on the other, Della Porta (1995) finds it linked to their closing. In fact, she finds that closure leads to a radicalization of actions.

In Canada, those looking at the women's movement tie the presence of opportunities to mobilization. For example, Bashevkin (1996) and Vickers et al. (1993) find that rates and types of activity by the National Action 
Committee on the Status of Women (NAC) and other women's organizations are linked to legal opportunities and the Constitutional process.

For Canadian Aboriginals, many institutional and political opportunities emerged over the years, as a result of both opening and closing of the polity. For instance, from the 1970s onward, Aboriginal peoples increasingly accessed federal funds. Trudeau's "just society" initiative saw unprecedented amounts of monies lent or granted to newly emerging organizations. Aboriginals also experienced a new openness of courts to their land claims and lawsuits. The successful recognition of past treaties in the Calder decision, the victory of the James Bay Cree fight against Hydro Quebec, and a seat at the table in drafting and ratifying section 35 of the Constitution Act, 1982 are all examples of this. Yet, at the same time, much openness came in response to unprecedented protest against closing opportunities, such as the proposed dissolution of the Indian Act in 1969 or failure to include Aboriginal peoples in the 1990 Meech Lake Accord. Thus, for Canadian Aboriginal protest, it is difficult to anticipate the direction of this relationship. Political opportunities may have both positive and negative effects on protest. As a result, I only hypothesize its significance rather than its direction:

H2: Opening and closing opportunities in dominant institutions significantly affect the rate of Aboriginal protest in Canada.

Like the resource mobilization literature, the political opportunity perspective also faces a number of criticisms. Perhaps the most striking is that it means everything and nothing at the same time. Although it is appealing for its "common sense" application and the ease one finds in citing examples of opportunity, its key problem is that most opportunities are assigned after-thefact, in clear hindsight. Attempts to operationalize it have led to rather mixed results and remain elusive (Meyer, 2004; Meyer and Minkoff, 2004). Also, attention to political opportunity is accused of missing the essence of mobilization, focusing too much on structural influences at the cost of micromobilization or day-to-day interactions among movements and their members.

The collective identity literature, by contrast, accounts for some of these omissions by trying to understand micro-mobilization. It looks at how movements and bystander publics interact in order to assert and build identities. According to this perspective, mobilization is intrinsically linked to one's identity. As Melucci (1988) notes, mobilization is bound to everyday interactions and social networks. People act on identities or bonds constructed through mundane interactions. Without a common identity, or shared social capital, there is little success in getting people to act contentiously. Others go further, arguing that in a postmodern world grievances have moved from material issues to those based on identity. Inglehart (1990) calls this a "culture shift." 
Whereas movements at the end of the $19^{\text {th }}$ century were grounded in class inequalities, movements of the $21^{\text {st }}$ century are based on the assertion and reaffirmation of denied identities. Some proponents of collective identity even go so far as arguing that participation in contentious action is a part of the social construction of that very identity. ${ }^{5}$ Thus, the goal of protest is recognition of disenfranchised identities rather than attaining more measurable material outcomes.

Scholars of nationalism also associate identity with contentious action. As Fanon (1967) wrote, mobilization is based on its denial. Cornell (1988), Johnson et. al. (1997), Johnson (1996), and Nagel (1996), who all look at the American Indian Movement (AIM), find that its rise in the 1970s was linked to the creation of a new PanAboriginal identity - one that extends beyond a single linguistic, cultural, or national group. They argue that opening and closing political opportunities and the creation of a new PanAboriginal identity led to widespread Indigenous contention in the US. Scholars who look at Indigenism in other countries concur. For example, Lucero (2003), Perreault (2001: 394), and Sawyer (1997: 78), all looking at the Ecuadorian case, find that traditionally separate Indigenous groups banded together leading to widespread Indigenous mobilization there. The importance of PanAboriginality was also considered relevant in Bolivia (Bebbington, 2001) and Venezuela (Van Cott, 2003). Even so, much of the work on Canadian Aboriginal mobilization ignores this aspect of contentious action.

Much work addresses identity but only as it relates to specific First Nations - for example, Mi'kmaq, Mohawk, Cree, Lubicon or Haida — rather than looking at broader Aboriginal movements. However, as noted above, there are some exceptions (e.g. Wilkes, 2004; Carroll and Ratner, 1996a; 1996b; Long, 1992 and Tennant, 1990). Nevertheless, of these, Wilkes focuses only on status-Indians, Carroll and Ratner and Tennant look only at Aboriginals in British Columbia, and Long, like Tennant, provides only an historical account. ${ }^{6}$ Failure to systematically examine PanAboriginal mobilization across Canada over an extended period of time is particularly interesting, given the rise of organizations like the Congress of Aboriginal Peoples, representing all Aboriginal $^{7}$ people regardless of status or nationality, or the Assembly of First

5. For an overview and critique of this literature, see Polleta and Jasper (2001).

6. Although Tennant, in particular, provides a highly useful historical account of Aboriginal mobilization in British Columbia, such studies are usually subject to ebbs and flows of the author's narrative approach to the time period studied, where some events are highlighted more than others for illustrative purpose and clarity (Sewell, 1996; Tarrow, 1996).

7. Here I distinguish between Aboriginal, which I use to refer to all Indigenous groups, versus Indian, status-Indian, First Nations or Inuit, referring to those who have specially recognized legal status in section 35 of the Canadian Constitution; or the Métis who are recognized but have a more ambiguous status; and non-status Indians who have lost their Indian status. 
Nations, representing bands from across the country. This is not to mention the Inuit Tapiriit Kanatami, the Métis National Council, or Native Women's Association of Canada, who also draw on PanCanadian and PanAboriginal constituencies. Such organizations have significantly influenced the negotiation of Canadian-Aboriginal relations over the last 35 years, especially on Constitutional matters, and have framed many prominent Aboriginal protests. As a result, I hypothesize:

H3: Increases in Aboriginal protest are related to the rise of PanAboriginality.

Like McAdam et al. (2001), I believe no single explanation best accounts for mobilization and that it is more appropriate to pick and chose among reliable alternatives; that is, to use each perspective as a plausible tool to highlight relevant influences on the movement(s) being studied. Thus, aspects of all three perspectives may account for Aboriginal protest. The goal of this paper is to determine which ones.

\section{Methods}

Unlike many accounts of Canadian Aboriginal mobilization, which rely on interviews, ethnographies, or historical analysis, this paper draws its conclusions from quantitative methods. This allows me to examine broad trends in Canadian Aboriginal protest, extending the generalizability of my conclusions beyond specific communities or isolated events.

\section{Dependent Variable: Aboriginal Protest}

Like other studies examining protest over a long period of time, I collected data from a content analysis of newspaper coverage of events. Articles between 1951 and 2000, covering a contentious action and mentioning one or more of the following keywords: Native, Indian, Inuit, Eskimo, and Métis, ${ }^{8}$ in the Globe and Mail were coded. Protest was operationalized as any act outside the dominant political process with a clear target, actor, place, action, and goal ${ }^{9}$; for example, the use of sit-ins, marches, public disturbances, civil disobedi-

8. The keyword Native was used alone for the 1991-2000 search of the Globe Information Services CD-Rom. All of the keywords were used in the search of the Canadian Newswire Index and manual search of articles before 1977. The reason for the change in key words is that the CD-Rom is more comprehensive in its search, cross-referencing other keywords under "Native" and because in earlier periods articles were more likely to be filed under "Indian."

9. If more than two of these were missing the article was not coded. 
ence, armed standoffs, blockades, riots, or violent acts for the purpose of challenging authorities. I coded these from the Globe and Mail because it is the longest running "national" ${ }^{10}$ Canadian newspaper and was indexed in the Globe Information Services CD-Rom (1991-2001) and Canadian News Index (1977-1990). When I began my research, the Globe \& Mail: Canada's Heritage from 1844 website was not available and thus articles before 1977 were coded from the first section of each day's hard copy issue. A total of 948 actions were coded, of which 616 were protest actions by Aboriginals.

Even though some have cautioned against using newspaper data to code events (c.f. Earl et al., 2004; Smith et al., 2001; McCarthy et al., 1996) and others warn against using a single source (c.f. Mueller, 1997; Swank, 2000; Koopmans and Rucht, 2002), the coding of the Globe and Mail alone was the only feasible means of collecting data on protest for a 50 year period. It is important to code data for the entire period because it allows examination of widespread trends rather than looking at isolated communities and events. Likewise, to my knowledge, this will be the first quantitative analysis of Canadian protest looking at the entire second half of the $20^{\text {th }}$ century. And, unlike many studies looking at protest events, I will not draw on the dependent variable for explanatory causes. Instead, my data obtain additional information from a number of other sources as measures of potential "causes" of protest.

Independent Variables: Resource Mobilization, Political Opportunity, and Collective Identity

One explanation of contentious action is resource mobilization. I measure this in two ways, looking at the rate of founding new Aboriginal organizations and Indian and Northern Affairs Canada (INAC) budgets. Following Couton and Cormier (2001), I code the founding of organizations from those filing letters of patent in the Canada Gazette, Canada Corporations Bulletin, and Canada

10. National is placed in quotations because many question the true representativeness of "national" newspapers (e.g. Oliver and Maney, 2000: 495). Indeed, most of the protests coded in my dataset took place in Ontario. However, even though they account for $38 \%$ of all protests, $35 \%$ of the organizations founded during the same period were in the same province. Moreover, the province with the largest Aboriginal population is also Ontario and all of the national Aboriginal political organizations have offices there. When this minimal bias is compared against other provinces similar results are found. The provinces whose protests were most "over-covered," in relation to organizational founding, are British Columbia and Manitoba. Yet, once population is considered, increased coverage makes sense. Thus, like all measures coding articles, there is some bias; however, the distribution of protests coded is roughly in-line with that of organizations founded (potential for mobilization) and population. 
Corporations Directorate. ${ }^{11}$ All organizations by law must register their name in the Canada Gazette. ${ }^{12}$ A total of 510 organizations were coded between 1951 and 2000. These were defined as organizations mentioning Native, Indian, Inuit, Eskimo, Métis, or the name of a recognized Aboriginal people or First Nation in the title, charter, or amendment filed.

I examine letters of patent because they are a consistent way of accounting for the number of new organizations and because the Gazette is one of the few records that track civic organizations in Canada. Even so, the data do not track organizations over time, only their founding. Although alternative sources, such as the Yearbook of International Organizations, account for organizational collapse, they are less precise because they cover only specific types of organizations, omitting others that are recorded in the Gazette. Likewise, recent INAC data on organizations in the Basic Department Data report figures for only the last few years. Thus, I use the Gazette because more Aboriginal organizations are recorded and it offers consistent data over a longer period of time than alternative sources.

The rate of founding new organizations is examined because prominent studies in the area (see Minkoff, 1997; McAdam, 1982; Morris, 1981) find that organizations are important sites of mobilization associated with protest. Resource mobilization theory prizes the role organizations play in contentious action and therefore I expect that as more organizations are founded, protest will increase.

Resource mobilization is also measured by the availability of government funding, examined by INAC budgets. These were used because the department allocates monies to Aboriginal organizations and also transfers funds to reserves and First Nations, which in turn may use them to mobilize people contentiously (Fleras and Elliott, 1992; Tennant, 1990). Likewise, discussions with representatives of Aboriginal organizations in four provinces revealed that federal money plays a large role in their core funding (Ramos, 2004). These data were gathered from federal budgets recorded in the Treasury Board Estimates, Part III, for each year, 1951-2000. Budget estimates were transformed into constant 2000 Canadian dollars and then aggregated by year. I expect that as INAC budgets increase, so does the rate of protest.

11. Letters of Patent were coded from the Canada Corporations Directorate (http://dsppsd.pwgsc.gc.ca/Collection-R/Bulletin/titles-e.html — last accessed 11/07/2005) May 1996-2000, from the Canada Corporations Bulletin 1985 - April 1996 and the Canada Gazette Pt. 1 1951- 1984.

12. A brief caveat is worth noting. These figures do not account for organizations that filed with provincial gazettes, organizations that filed before the 1950 s, or organizations that did not file a patent for their name. 
Another possible influence is political opportunity, which is measured by three variables: average newspaper coverage, land claims settled and Supreme Court decisions ruling on Aboriginal people(s) or issues. I coded average newspaper coverage of articles reporting Aboriginal mobilization from the Globe and Mail. ${ }^{13}$ These include articles on contentious actions by nonAboriginals on Indigenous issues, as well as media and legal actions not included in the current analysis. This was used as a measure of media or contextual openness to Aboriginal issues. However, some might argue that coverage is the result of protest rather than an opportunity for more protest. Here I partially agree, noting that articles appear in the press because of protests and other contentious actions. Nevertheless, the amount of press offered is also an opportunity because most movements communicate with bystander publics via mediated news. Media prominence is associated with the ability to shape stories, communicate with potential supporters and generate resources (Ryan et al., 2001; Gamson and Wolfsfeld, 1993). Thus, I anticipate the longer the mean length of articles covering contentious action in a given year, the more open the media, the greater the chance of mobilizing bystanders, and in turn the more protest.

I also examine political-legal opportunities as a possible influence on protests. This is done through the number of land claims settled in a given year. ${ }^{14}$ These data were obtained from email correspondence with INAC and from the Comprehensive Claims Policy and Status of Claims, February 2003 report (INAC, 2005; 2003). ${ }^{15}$ Both types of claims were added together to decrease potential multicolinearity in the model. ${ }^{16}$ These data are included because of the significant role land claims play in Aboriginal mobilization. The

13. Length was determined by counting any paragraph over 5 lines. Those less than five lines were combined to the closest five-line paragraph.

14. In Canada there are two types of land claims, Specific and Comprehensive land claims. The former are those that "arise from alleged non-fulfilment of treaties or other legal obligations, or from the alleged improper administration of lands and other assets under the Indian Act or other formal agreements" (http://www.parl.gc.ca/information/library/PRBpubs/prb9917-e.htm — last accessed 11/07/2005). The latter "are based on the assertion of continuing Aboriginal rights and claims to land that have not been dealt with by treaty or other means" (http://www.aincinac.gc.ca/ps/clm/ccb_e.html — last accessed 11/07/2005).

15. The file received from INAC only contained data on specific land claims from 1970 onward. However, Canada did not have a specifics claims policy until 1973 (http://www.aincinac.gc.ca/pr/info/info121_e.html — last accessed 11/07/2005). Moreover, the federal government was unwilling to negotiate comprehensive claims until after the Supreme Court's Calder decision during the same year and the first comprehensive claim documented was in 1975 (INAC, 2003). As a result, it was assumed that no claims were settled before years of available data.

16. Specific and Comprehensive claims are strongly correlated $(\mathrm{r}=0.50)$. Many statisticians encourage merging similar measures to avoid multicolinearity (Kennedy, 1998). 
last 20 years saw an explosion of legal scholarship looking at Aboriginal rights and treaties. This is because some of the most prominent and successful instances of Aboriginal mobilization, such as the Nisga'a, the Denede, or James Bay Cree movements, were based on legal rights (cf. Mainville, 2001; Cairns, 2000; Flanagan, 2000; Grand Council of the Crees, 1998). Disputes over land and fulfilment of treaty obligations are very prominent grievances among status-Indians and Métis. Moreover, the settlement of land claims generates resources for specific communities and demonstrates to others the fruitfulness of pursuing Aboriginal rights. Thus, any account of Aboriginal contentious action should take this into consideration. Resolutions of land claims are extremely visible national, political, financial, and legal opportunities for Aboriginals.

Political-legal opportunities arising from Supreme Court decisions ruling on Aboriginal peoples or issues are also considered. Supreme Court decisions mentioning Indian, Inuit, Eskimo, or Métis in the decision's "catchwords," "headnotes," or title between 1951 and 2000 were coded. The Lexis-Nexis database was used to search the Canadian Supreme Court Reports. ${ }^{17}$ A total of 108 decisions were coded, which were later aggregated by year. Although some might consider looking at "critical" decisions instead of all decisions, I chose not to do this because of my interest in overall context over particular decisions. Moreover, there is much difficulty in quantifying "significant" decisions over others.

The number of Supreme Court decisions in a given year is used as a measure of opportunity because other Canadian scholars looking at the women's movement (Bashevkin, 1996; Vickers et al., 1993) consider them important. Moreover, scholars looking at Aboriginal-Canadian relations largely credit Supreme Court decisions, such as the Calder decision in 1973, with opening the dominant polity for Aboriginal organizations and issues (Asch, 1993:53; Fleras and Elliott, 1992:44). Likewise, decisions such as Marshall in 2000 have also been directly associated with increased protest by both Aboriginals and non-Aboriginals (Coates, 2000). Thus, it is important to consider these factors when analyzing the influences on Aboriginal protest.

As noted in hypothesis two, I am agnostic to the direction of political opportunity's influence; however, expect that each measure (average media coverage, land claims settled and Supreme Court decisions) will be statistically significant. A third account of protest is collective identity. Although most studies look at it through qualitative, ethnographic or historical data, I examine it crudely by looking at the rate of founding two levels of organizations:

17. The search was conducted on December 11, 2002. 
"community" and "PanAboriginal." These data are disaggregated from the total number of organizations founded already outlined above. Community organizations were coded as those that represent a single community, status group, or locale as defined by their letters of patent. These include community associations, clubs, service providers, or even political organizations, as long as they were limited to a single community. PanAboriginal organizations were considered those representing more than one community, status group, or locale as defined by their letters of patent. These included political organizations, professional associations, and regional, provincial, and national movements or organizations.

The founding of both types of organizations is considered a rough proxy for the growth of particular types of identification, local and PanAboriginal. Although identities are fluidly negotiated and often contradictory, the rate of founding new organizations measures the site where potential interaction takes place. Some, such as Melucci (1988), argue movement identities are negotiated via informal interactions, which this measure does not capture. Some scholars also stress the need to create community ties and networks, which the founding of organizations measures only indirectly (Staggenborg, 1996; Buechler, 1990). However, others looking at social capital (e.g. Putnam, 2000) argue that organizations and associations are the very sites that facilitate this negotiation and create ties. Thus, although crude and interpretation should be made with caution, this measure allows for systematic analysis of the development of different sites of identity negotiation. I expect that as the rate of founding both types of organization increases, so do local and PanAboriginal collective identities and in turn protest.

The rate of Aboriginal protest is analyzed by regressing it on resource mobilization, political opportunity, and collective identity variables. Because the dependent variable is a count of protest, I use negative binomial models suited to the specificities of count data. Unlike Poisson models that assume the variance is equal to the mean, negative binomial models are not bound by this assumption, which my data violate (cf. Cameron and Trivedi, 1986; King, 1989; Long, 1997). Because the data are a time-series they are prone to problems of autocorrelation. To correct for this a lag term is included in comparison models.

\section{Analysis}

Three explanations of why people mobilize were offered: resource mobilization, political opportunity, and collective identity. Graph 1, tracking Aboriginal protest during the 1951-2000 period, offers evidence that each perspective might account for Aboriginal protest. 


\section{Canadian Journal of Sociology}

\section{Table 1. Variables and Operationalization}

\begin{tabular}{|c|c|c|c|}
\hline Variable & Operationalization & Source & $\begin{array}{l}\text { Expected } \\
\text { Relation }\end{array}$ \\
\hline Protest & $\begin{array}{l}\text { The total number of protest and } \\
\text { violent actions by Aboriginals } \\
\text { in a given year, 1951-2000. }\end{array}$ & $\begin{array}{l}\text { Globe and Mail. Articles were } \\
\text { obtained from the Globe Infor- } \\
\text { mation Services CD-ROM } \\
\text { (1991-2001). Canadian News } \\
\text { Index (1977-1990), and the } \\
\text { first section of every issue from } \\
1951 \text { to the end of } 1976 .\end{array}$ & $\begin{array}{l}\text { Depen- } \\
\text { dent } \\
\text { Variable }\end{array}$ \\
\hline $\begin{array}{l}\text { Founding } \\
\text { organizations }\end{array}$ & $\begin{array}{l}\text { The total number of Aboriginal } \\
\text { organizations that filed a letter } \\
\text { of patent in a given year, 1951- } \\
2000 .\end{array}$ & $\begin{array}{l}\text { Canada Gazette, Canada Corpo- } \\
\text { rations Bulletin, and Canada } \\
\text { Corporations Directorate. }\end{array}$ & + \\
\hline $\begin{array}{l}\text { Founding } \\
\text { community } \\
\text { organizations }\end{array}$ & $\begin{array}{l}\text { The number of organizations } \\
\text { that represents a single commu- } \\
\text { nity, status group, or locale } \\
\text { filing a letter of patent in a } \\
\text { given year, 1951-2000. }\end{array}$ & $\begin{array}{l}\text { Canada Gazette, Canada Corpo- } \\
\text { rations Bulletin, and Canada } \\
\text { Corporations Directorate. }\end{array}$ & + \\
\hline $\begin{array}{l}\text { Founding } \\
\text { PanAboriginal } \\
\text { organizations }\end{array}$ & $\begin{array}{l}\text { The number of organizations } \\
\text { that represents more than one } \\
\text { community, status group, or } \\
\text { locale filing a letter of patent } \\
\text { in a given year, 1951-2000. }\end{array}$ & $\begin{array}{l}\text { Canada Gazette, Canada Corpo- } \\
\text { rations Bulletin, and Canada } \\
\text { Corporations Directorate. }\end{array}$ & + \\
\hline $\begin{array}{l}\text { INAC budget, } \\
\text { in millions }\end{array}$ & $\begin{array}{l}\text { The budget estimate for the } \\
\text { Department of Indian and } \\
\text { Northern Affairs Canada for } \\
\text { a given year, 1951-2000. } \\
\text { Constant (2000) CND\$. }\end{array}$ & $\begin{array}{l}\text { Treasury Board Estimates, } \\
\text { Part III. }\end{array}$ & + \\
\hline $\begin{array}{l}\text { Average } \\
\text { newspaper }\end{array}$ & $\begin{array}{l}\text { The average yearly length of } \\
\text { articles in the Globe and Mail } \\
\text { covering contentious action on } \\
\text { Aboriginal issues, } 1951-2000 \text {. } \\
\text { Length was measured by number } \\
\text { of paragraphs in an article. }\end{array}$ & Globe and Mail. & $+/-$ \\
\hline $\begin{array}{l}\text { Land claims } \\
\text { settled }\end{array}$ & $\begin{array}{l}\text { The number of Specific and } \\
\text { and Comprehensive Land } \\
\text { Claims settled within a given } \\
\text { year, 1951-2000. }\end{array}$ & $\begin{array}{l}\text { Department of Indian and } \\
\text { Northern Affairs Canada. }\end{array}$ & $+/-$ \\
\hline $\begin{array}{l}\text { Supreme Court } \\
\text { decisions }\end{array}$ & $\begin{array}{l}\text { The total number of court } \\
\text { cases ruling on an Aboriginal } \\
\text { person or dealing with Abori- } \\
\text { ginal issues in a given year, } \\
\text { 1951-2000. }\end{array}$ & Supreme Court Reports & $+/-$ \\
\hline
\end{tabular}


What Causes Canadian Aboriginal Protest? 223

Table 2. Descriptive Statistics

Variable

Protest

Founding organizations

Founding community organizations

Founding PanAboriginal organizations

INAC budget, in millions

Average newspaper

Land claims settled

Supreme Court decisions

\begin{tabular}{rrcc} 
Mean & Std. Dev. & Min. & Max. \\
& & & \\
12.32 & 15.09 & 0 & 91 \\
10.20 & 12.35 & 0 & 50 \\
5.76 & 7.30 & 0 & 31 \\
4.06 & 4.90 & 0 & 17 \\
673.35 & $1,835.61$ & 14.64 & $5,480.04$ \\
9.18 & 3.60 & 0 & 15.93 \\
4.84 & 8.23 & 0 & 33 \\
2.16 & 2.38 & 0 & 12 \\
\hline
\end{tabular}

Graph 1. Canadian Aboriginal Protest, 1951-2000

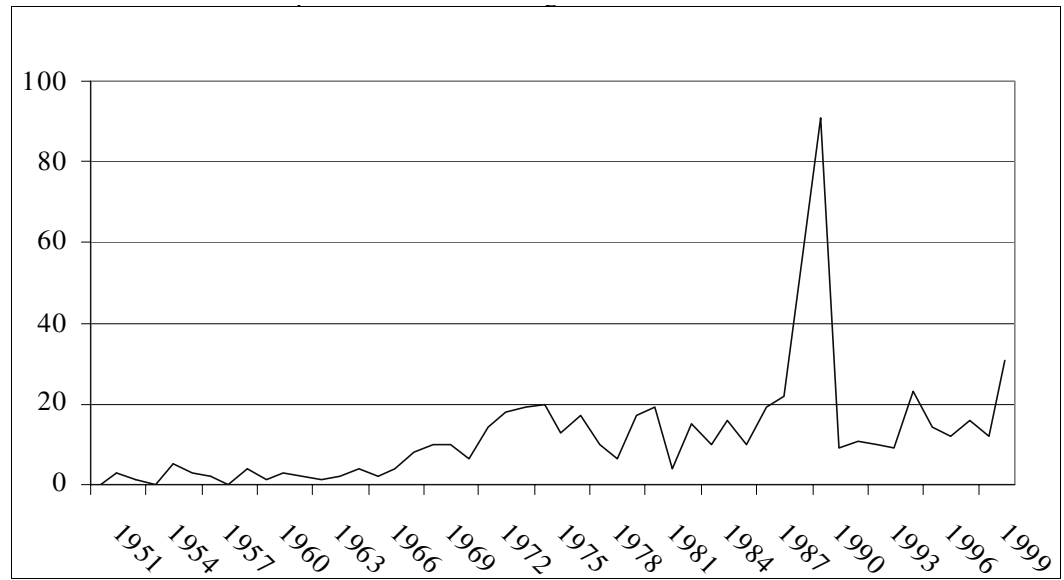

As one can see, the first dramatic increase in the number of Aboriginal protests in a given year occurs in the late 1960s; after this, there is increase in the mid-1970s and the early 1980s; it is followed by an explosion of contention in 1989 and then again in 1990; and then high levels of protest in the mid and late 1990s.

If one interprets these findings using the resource mobilization perspective, s/he finds an increase in the rate of founding organizations during the late 1960s and early 1970s. In fact, three of the largest national level PanAboriginal organizations were founded during this period. For example, the National Indian Brotherhood (NIB) ${ }^{18}$ began organizing in the late 1960 s and filed its

18. This organization later became the Assembly of First Nations, representing status-Indians. 
letter of patent with the Gazette in 1970. The Inuit Tapiriit Kanatami (ITK) and Native Council of Canada (NCC) ${ }^{19}$ were also both organizing during the same period and filed their letters of patent in 1972. As noted above, during the same period the federal government began funding Aboriginal organizations (Fleras and Elliott, 1992). Thus, organizational resource capacity may account for this increase in contention. There is also support for the notion of political opportunities. Recall, the Calder decision occurred in 1973, and the first contemporary land claim was settled in 1975, perhaps accounting for increased mobilization during the mid-1970s. Likewise, unprecedented opportunities emerged in the early 1980s with the patriation of the Constitution, perhaps contributing to increased protest then. It can also be argued that closing opportunities with the exclusion of Aboriginals in the Meech Lake Accord may explain the eruption of protest in 1990. However, resources and opportunities both increased and decreased in earlier periods without the same levels of protest. Perhaps PanAboriginal identity accounts for the most recent increase. In fact, $38.5 \%$ of protests by Aboriginals during 1990 were in support of another Aboriginal group or protest, the highest level of any year observed. Likewise, of these, $13 \%$ of protests were by PanAboriginal organizations or people associated with them.

To examine these claims in greater detail, regression analysis is conducted in Table 3. In Model 1, protest is regressed on a series of variables measuring resource mobilization and political opportunity for the 1951 to 2000 period. The model offers partial support for the resource mobilization and political opportunity perspectives. The rate of founding organizations, INAC budget, average length of newspaper coverage, and the number of land claims settled were all statistically significant. As the number of organizations founded in a given year increases, so does the rate of protest. The same applies for INAC budget and average newspaper coverage of contention. Land claims settled have the opposite effect. As the number of claims settled in a given year increases, the rate of protest decreases. The number of Supreme Court decisions in a given year did not yield a significant effect. When they are disaggregated into decisions in favour and against Aboriginals, both remain insignificant. The model has a pseudo $\mathrm{R}^{2}$ of 0.1381 . Although the model fit is modest, the same variables regressed using other methods obtain much stronger fits. This is not to say, however, that the inclusion of other factors would not improve the model.

19. Originally the NCC set out to build a broad movement organization representing all Aboriginal peoples, including status and non-stats Indians, as well as Métis, but now predominantly represents non-status Indians alone and has changed its name to the Congress of Aboriginal Peoples. 
Table 3. Factors Influencing Canadian Aboriginal Protest, 1951-2000 (negative binomial models, with robust standard errors in parentheses)

\begin{tabular}{|c|c|c|c|c|c|}
\hline & 1 & 2 & 3 & 4 & 5 \\
\hline \multirow[t]{2}{*}{ Lag Term } & - & 0.0105 & - & 0.0105 & - \\
\hline & - & (0.0103) & - & $(0.0106)$ & - \\
\hline \multirow[t]{2}{*}{ Founding organizations } & $0.0415^{* *}$ & $0.0353^{*}$ & - & - & - \\
\hline & $(0.0179)$ & $(0.0185)$ & - & - & - \\
\hline \multirow{2}{*}{$\begin{array}{l}\text { Founding community } \\
\text { organizations }\end{array}$} & - & - & $0.0462 *$ & 0.0389 & - \\
\hline & - & - & $(0.0256)$ & $(0.0269)$ & - \\
\hline \multirow{2}{*}{$\begin{array}{l}\text { Founding PanAboriginal } \\
\text { organizations }\end{array}$} & - & - & - & - & 0.0543 \\
\hline & - & - & - & - & $(0.0469)$ \\
\hline $\begin{array}{l}\text { INAC budget, in } \\
\text { millions }\end{array}$ & $\begin{array}{l}0.0003 * * \\
(0.0001)\end{array}$ & $\begin{array}{l}0.0003 * * * \\
(0.0001)\end{array}$ & $\begin{array}{l}0.0004^{* * *} \\
(0.0001)\end{array}$ & $\begin{array}{l}0.0004 * * * \\
(0.001)\end{array}$ & $\begin{array}{l}0.0004 * * * \\
(0.0002)\end{array}$ \\
\hline Average newspaper & $\begin{array}{l}0.1008 * * * \\
(0.0292)\end{array}$ & $\begin{array}{l}0.0777 * * \\
(0.0320)\end{array}$ & $\begin{array}{l}0.0910 * * * \\
(0.0273)\end{array}$ & $\begin{array}{l}0.0692 * * \\
(0.0302)\end{array}$ & $\begin{array}{l}0.0964 * * * \\
(0.0315)\end{array}$ \\
\hline Land claims settled & $\begin{array}{l}-0.0959 * * * \\
(0.0197)\end{array}$ & $\begin{array}{l}-0.0920 * * * \\
(0.0222)\end{array}$ & $\begin{array}{l}-0.0945^{* * *} \\
(0.0200)\end{array}$ & $\begin{array}{l}-0.0911 * * * \\
(0.0232)\end{array}$ & $\begin{array}{l}-0.0890^{* * * *} \\
(0.0222)\end{array}$ \\
\hline Supreme Court decisions & $\begin{array}{c}0.0680 \\
(0.0590)\end{array}$ & $\begin{array}{c}0.0346 \\
(0.0551)\end{array}$ & $\begin{array}{c}0.0522 \\
(0.0645)\end{array}$ & $\begin{array}{c}0.0197 \\
(0.0592)\end{array}$ & $\begin{array}{c}0.0517 \\
(0.0540)\end{array}$ \\
\hline Constant & $\begin{array}{l}0.6111^{* *} \\
(0.3065)\end{array}$ & $\begin{array}{l}0.8072 * * * \\
(0.3158)\end{array}$ & $\begin{array}{l}0.7071^{* *} \\
(0.2962)\end{array}$ & $\begin{array}{l}0.8938 * * * \\
(0.3065)\end{array}$ & $\begin{array}{l}0.6800^{* *} \\
(0.3161)\end{array}$ \\
\hline $\operatorname{Prob}>\chi^{2}$ & 0.000 & 0.000 & 0.000 & 0.000 & 0.000 \\
\hline Pseudo $\mathbf{R}^{2}$ & 0.1381 & 0.1419 & 0.1355 & 0.1396 & 0.1308 \\
\hline
\end{tabular}

* Significant at the .10 level

** Significant at the .05 level

*** Significant at the .01 level

Because early diagnostics showed signs of autocorrelation, a lag term was included in Model 2. As one can see from the results, the term is not statistically significant and the model changes only marginally. Founding organizations, INAC budget, average newspaper coverage, and land claims settled remain significant and have the same, but decreased, effects on protests. The overall model fit improves only slightly.

Models 1 and 2 support hypotheses outlined above. Resource mobilization appears to increase the rate of Canadian Aboriginal protest; both founding organizations and INAC budget significantly do so. Nevertheless, measures of political opportunity are less clear-cut. Although average length of newspaper coverage is significant and increases protest, Supreme Court decisions are not, and land claims settled have a negative effect. Thus, opening and closing opportunities affect protest in different ways.

Model 3 examines a proxy of collective identity by looking at the rate of founding community organizations. Like the general founding of organiza- 
tions, these are statistically significant and increase the rate of Aboriginal protest. The relationship among the other variables and protest remains more or less the same. Model 4 runs the same regression but includes a lag for the rate of protest. When this is incorporated, the lag is not statistically significant, but neither is the effect of community organizations. However, if violent actions are disaggregated from non-violent protests, these organizations continue to remain significant even when the lag is included. Thus, there is partial support of local identity fostering protest. However, in Model 5, which looks at the impact of a proxy of PanAboriginal identity, we find it does not have a significant effect on protest. It appears as though collective identity matters, but only that based on local identities and largely on non-violent actions.

\section{Discussion}

The findings show that the most consistent influences on Canadian Aboriginal protest are resource mobilization, political opportunities and local identities. Unlike scholars looking at Indigenous mobilization in other countries, there is little support for the role of PanAboriginal identity.

The weakness of PanAboriginal identity is partially explained by the rough proxy measuring it, the level of organizations founded. As noted above, this measures only potential sites of negotiating identity and fostering ties, rather than the actual processes of interaction generating identity. To fully understand the role of PanAboriginality in the Canadian context, further examination with different data is needed. However, with this caveat noted, another reason for its lack of significance is the reification of differences among Aboriginal peoples through historical colonization and the federal government's continued practice of recognizing different status groups. In fact, when this is considered in relation to the significance of resource mobilization and political opportunities, it becomes even more apparent. Both resources and opportunities are largely allocated to specific local communities and status groups rather than PanAboriginal organizations or all Aboriginals.

For example, even though all Aboriginals faced losing their "status" and hope of gaining recognition with the proposed 1969 White paper, it was defeated and followed by a political vacuum and a decade of increased federal funding of Aboriginal organizations along existing status lines. The federal government established a core funding program in 1971 to provide Aboriginals and other interest groups with the resources to promote and pursue their causes at a federal level (Comeau and Santin, 1990; Fleras and Elliott, 1992). However, because of differing histories of colonization and legal statuses imposed on Aboriginals, a number of different national political organizations emerged, representing the grievances of different Aboriginal peoples rather than the common interests among them. As a result, the NIB represented 
status-Indians, the NCC non-status and urban Indians as well as Métis, and the ITK the Inuit. Although some Aboriginal activists, such as Jack Emms, a founding member of the NIB, cautioned against relying on federal funding, organizations increasingly saw it as their main source of financial resources (Young, 1969). However, as Emms foresaw, reliance on government funds came at the cost of competition over a limited pool of resources and increasing divisions among Aboriginals. For instance, looking at British Columbian Aboriginal organizations, Tennant found that "separate and massive" funding largely inhibited creating a broad based movement in that province (1990: 173). Thus, reliance on government funding, allocated to specific status groups, led to divisions among Aboriginals and presented a major obstacle to PanAboriginal mobilization or identity formation.

At the same time, differing statuses also changed the way Aboriginals perceived political opportunities and grievances. Most land claims and court cases were filed by status-Indians and most settlements applied only to them; many also only affected specific communities or First Nations rather than all Aboriginals. Thus, although the James Bay Cree settled the first contemporary land claim in 1975, it directly affected the lives of only the Cree and Naskapi in northern Quebec. Likewise, major court decisions, such as Calder in 1973 or Marshall in 2000, largely benefit only status-Indians and their applicability to the Métis and non-status Indians remains largely ambiguous. Thus, major political opportunities, like the patriation of the Constitution, aggravate differences among Aboriginals and inhibit broad based mobilization.

The original drafting of the Constitution recognized three Aboriginal peoples in section 35 but left much to be elaborated. Likewise, the Constitution Act, 1982 granted Métis formal recognition as Aboriginals for the first time in Canadian history, but did not specify which rights were recognized. Ambiguity in recognition eventually led to tension between the Métis and non-status Indians over the need to negotiate further specification of section 35 . The result of different perceptions of the section led to the Métis splitting from the PanAboriginal political organization representing both (the NCC) to form their own organization (The Métis National Council) shortly after (Chartier, 2002; Belcourt, 2002; Tennant, 1990). The original draft of the Constitution, moreover, didn't recognize equal applicability among Aboriginal men and women, which led the Native Women's Association of Canada to lobby against other national Aboriginal political organizations for representation of their own interests in amendment meetings between 1983 and 1987. Constitutional recognition thus entrenched different legal statuses, creating diverging grievances and perceptions of opportunities. As a result, like reliance on core funding from the federal government, pursuit of political-legal and Constitutional opportunities led to competition and divisions among organizations, again inhibiting broad based mobilization. 
In sum, although different organizations increasingly pursued the same resources and political-legal opportunities, differences in status broke the potential of fostering emerging coalitions of Aboriginals and led to an entrenchment of differences. This was evident in Models 3 through 5 of Table 3 , reported above, which all suggest that PanAboriginal collective identity was not a significant factor driving Aboriginal protest in the 1951 to 2000 period.

\section{Conclusion}

Overall the findings provide mixed support for two of the three perspectives used to account for mobilization. The significance of the founding of organizations and INAC budgets shows that resource mobilization is an important factor driving Aboriginal protest. As more organizations were founded in a given year, protest increased. Organizations acted as hubs that pooled material resources and human capital, which were later exploited for contentious action. Likewise, INAC budgets were also found to increase protest. Even so, federal funds were also a hindrance to mobilization because of competition that emerged among organizations seeking them. In fact, unequal access to federal monies led to tension among organizations. Both findings support existing literature and my first hypothesis: increases in resources contributed to increased protest.

However, resources alone do not account for protest. Instead, movements need them to respond to and exploit emerging opportunities. Regression analysis also shows that political opportunity contributed to Canadian Aboriginal protest. For example, increased media reporting offered greater attention to Aboriginal issues and increased protests; conversely, resolution of grievances, through the settlement of land claims, decreased contention. Again, these findings support the existing literature, which shows that opportunities can both increase and decrease mobilization. They also support my second hypothesis which was agnostic to the direction of their relationship with protest and only expected significance.

Although my measures of identity were rough proxies, they suggest that PanAboriginal identity was not a significant factor driving Canadian Aboriginal protest. With caveats noted, I argued that competition and unequal access to resources and political-legal opportunities largely account for this. Ironically, then, it appears that government funding of national Aboriginal political organizations in the 1970 s, intended to increase engagement of the polity, ultimately led to divisions among Aboriginal peoples. Moreover, although funding provided resources needed to exploit new opportunities, it also led to competition among organizations. This resulted in further entrenchment of differences among Aboriginal peoples who pursued resources and opportunities locally or along Constitutionally recognized status groups — ultimately inhibiting the creation of a broader, more powerful, national movement. 
As a result, Aboriginal mobilization remains characterized by differences among communities, organizations, and status groups. It is likely to remain this way as long as national organizations are defined by legal status rather than broader interests that span across different Aboriginal groups and peoples. Moreover, continued dependence on core funding from the federal government likely will maintain competition among organizations and reify differences, muting the full potential of Aboriginal contention in Canada.

\section{References}

Adams, Howard

1975 Prison of Grass: Canada from the Native Point of View. Toronto: New Press.

1995 A Tortured People. Penticton, B.C.: Theytus Books.

Alfred, Taiaiake

1995 Heeding the Voices of our Ancestors: Kahnawake Mohawk Politics and the Rise of Native Nationalism. Toronto; New York: Oxford University Press.

Asch, Michael

1993 Home and Native Land: Aboriginal Rights and the Canadian Constitution. Vancouver: UBC Press.

Bashevkin, Sylvia

1996 "Losing Common Ground: Feminists, Conservatives and Public Policy in Canada during the Mulroney Years.” Canadian Journal of Political Science 29(2): 211-242.

Bebbington, Anthony

2001 "Globalized Andes? Livelihoods, Landscapes and Development." Ecumene 8(4): 414-436.

Belcourt, Tony

2002 Interview, February $2^{\text {nd }}$.

Buechler, Steven

1990 Women's Movements in the United States: Woman Suffrage, Equal Rights, and Beyond. New Brunswick, NJ: Rutgers University Press.

Cameron, A. Colin and Pravin K. Trivedi

1986 "Econometric Models Based on Count Data: Comparison and Applications of Some Estimators and Tests." Journal of Applied Econometrics 1(1): 29-53.

Cairns, Alan

2000 Citizens Plus: Aboriginal Peoples and the Canadian State. Vancouver: UBC Press.

Cardinal, Harold

1969 The Unjust Society: the Tragedy of Canada's Indians. Edmonton: M. G. Hurtig.

Carroll, William K. and R. S. Ratner

1996a "Master Framing and Cross-Movement Networking in Contemporary Social Movements.” The Sociological Quarterly 37(4): 601-625.

1996b "Master Frames and Counter-Hegemony: Political Sensibilities in Contemporary Social Movements." Canadian Review of Sociology and Anthropology 33(4): 407-435.

Chartier, Clem

2002 Interview, March $6^{\text {th }}$.

Coates, Ken S.

2000 The Marshall Decision and Native Rights. Montreal: McGill-Queen's University Press. 
230 Canadian Journal of Sociology

Comeau, Pauline and Aldo Santin

1990 The First Canadians: a Profile of Canada's Native People Today. Toronto: J. Lorimer.

Cornell, Stephen E.

1988 The Return of the Native: American Indian Political Resurgence. New York: Oxford University Press.

Couton, Phillipe and Jeffrey Cormier

2001 "Voluntary Associations and State Expansion in Quebec 1955-1970." Journal of Political and Military Sociology 29(1):19-45.

Della Porta, Donatella

1995 Social Movements, Political Violence, and the State: a Comparative Analysis of Italy and Germany. New York: Cambridge University Press.

Diani, Mario

1992 "The Concept of Social Movement." Sociological Review 40(1):1-25.

Donati, Paolo R.

1996 "Building a Unified Movement: Resource Mobilization, Media Work, and Organizational Transformation in the Italian Environmentalist Movement." Research in Social Movements, Conflicts and Change 19: 125-157.

Earl, Jennifer, Andrew Martin, John D. McCarthy and Sarah A. Soule

2004 "The Use of Newspaper Data in the Study of Collective Action." Annual Review of Sociology 30: 65-80.

Fanon, Frantz

1967 Black Skin, White Masks. New York: Grove Press.

Flanagan, Thomas

2000 First Nations? Second Thoughts. Montreal: McGill-Queen's University Press.

Fleras, Augie and Jean Leonard Elliott

1992 The "Nations Within": Aboriginal-State Relations in Canada, the United States and New Zealand. Toronto: Oxford University Press.

Fukuyama, Francis

1995 Trust: The Social Virtues and the Creation of Prosperity. New York: Free Press.

Gagné, Marie-Anik

1994 A Nation within a Nation: Dependency and the Cree. Montréal: Black Rose Books.

Gamson, William A. and Gadi Wolfsfeld

1993 "Movements and Media as Interacting Systems." Annals of the American Academy of Political \& Social Science 528 (July): 114-25.

Grand Council of the Crees

1998 Never Without Consent. Toronto: ECW Press.

INAC (Indian and Northern Affairs Canada)

2005 Personal email correspondence with Indian and Northern Affairs Canada, Rosa Maria Navas [navasr@ainc-inac.gc.ca.] Data file in adobe format: Number of land claims settled by FY. September 6.

2003 "Comprehensive Claims Policy and Status of Claims, February 2003." Indian and Northern Affairs Canada.

Inglehart, Ronald

1990 Culture Shift in Advanced Industrial Societies. Princeton: Princeton University Press.

Jenson, Jane and Martin Papillion

2000 "Challenging the Citizenship Regime: The James Bay Cree and Transnational Action." Politics \& Society 28(2): 245-264. 
What Causes Canadian Aboriginal Protest? 231

Johnson, Troy R.

1996 The Occupation of Alcatraz Island: Indian Self-Determination and the Rise of Indian Activism. Urbana: University of Illinois Press.

Johnson, Troy R., Joane Nagel, and Duane Champagne

1997 American Indian Activism: Alcatraz to the Longest Walk. Urbana: University of Illinois Press.

Kennedy, Peter

1998 A Guide to Econometrics. Cambridge, Mass.: MIT Press.

Killian, Lewis M.

1984 “Organization, Rationality and Spontaneity in the Civil Rights Movement." American Sociological Review 49(6): 770-783.

King, Gary

1989 "Variance Specification in Event Count Models: From Restrictive Assumptions to a Generalized Estimator.” American Journal of Political Science 33(3): 762-784.

Koopmans, Ruud and Dieter Rucht

2002 "Protest Event Analysis." Pp. 231-259 in Methods of Social Movement Research, edited by B. Klandermans and S. Staggenborg. Minneapolis: University of Minnesota Press.

Long, A. David

1992 "Culture, Ideology, and Militancy: The Movement of Native Indians in Canada, 1969-1991.” Pp. 118-134 in Organizing Dissent: Contemporary Social Movement in Theory and Practice, edited by W. Carroll. Toronto: Garamond Press.

Long, J. Scott

1997 Regression Models for Categorical and Limited Dependent Variables. Thousand Oaks: Sage Publications.

Lucero, José A.

2003 "Locating the "Indian Problem": Community, Nationality, and Contradiction in Ecuadorian Indigenous Politics." Latin American Perspectives 30(1): 23-48.

Mainville, Robert

2001 An Overview of Aboriginal and Treaty Rights and Compensation for their Breach. Saskatoon: Purich Publishing Ltd.

McAdam, Doug

1982 Political Process and the Development of Black Insurgency, 1930-1970. Chicago: University of Chicago Press.

McAdam, Doug, Sidney Tarrow and Charles Tilly

2001 Dynamics of Contention. New York: Cambridge University Press.

McCarthy, John D., Clark McPhail and Jackie Smith

1996 "Images of Protest: Dimensions of Selection Bias in Media Coverage of Washington Demonstrations, 1982 and 1991." American Sociological Review 61(3): 478-499.

Melucci, Alberto

1988 "Getting Involved: Identity and Mobilization in Social Movements." International Social Movement Research 1:329-348.

Meyer, David S.

2004 "Protest and Political Opportunities.” Annual Review of Sociology 30: 125-145.

Meyer, David S. and Debra C. Minkoff

2004 “Conceptualizing Political Opportunity." Social Forces 82(4): 1457-1492.

Minkoff, Debra. C.

1997 “The Sequencing of Social Movements.” American Sociological Review 62(5): 779-799. 


\section{Canadian Journal of Sociology}

Morris, Aldon

1981 "Black Southern Student Sit-In Movement: An Analysis of Internal Organization." American Sociological Review 46(6): 744-767.

Mueller, Carol

1997 "International Press Coverage of East German Protest Events, 1989." American Sociological Review 62(5): 820-832.

Nagel, Joane

1996 American Indian Ethnic Renewal: Red Power and the Resurgence of Identity and Culture. New York: Oxford University Press.

Niezen, Ronald

1998 Defending the Land: Sovereignty and Forest Life in James Bay Cree Society. Boston: Allyn and Bacon.

2003 The Origins of Indigenism: Human Rights and the Politics of Identity. Berkeley: University of California Press.

Oliver, Pamela E. and Gregory M. Maney

2000 "Political Cycles and Local Newspaper Coverage of Protest Events: From Selection Bias to Triadic Interactions.” American Journal of Sociology 106(2):463-505.

Oliver, Pamela E. and Daniel Myers

1999 "How Events Enter the Public Sphere: Conflict, Location, and Sponsorship in Local Newspaper Coverage of Public Events.” American Journal of Sociology 105(1): 38-87.

Pertusati, Linda

1997 In Defence of Mohawk Land: Ethnopolitical Conflict in Native North America. Albany: State University of New York Press.

Perreault, Thomas

2001 "Developing Identities: Indigenous Mobilization, Rural Livelihoods and Resource Access in Ecuadorian Amazonia.” Ecumene 8(4): 381-413.

Piven, Frances Fox and Richard A. Cloward

1991 "Collective Protest: A Critique of Resource Mobilization Theory.” International Journal of Politics, Culture \& Society 4: 435-458.

Polletta, Francesca and James Jasper

2001 "Collective Identity and Social Movements.” Annual Review of Sociology 27:283-305.

Putnam, Robert D.

2000 Bowling Alone: The Collapse and Revival of American Community. New York: Simon $\&$ Schuster.

Ramos, Howard

2004 "Divergent Paths: Aboriginal Mobilization in Canada, 1951-2000." Ph.D dissertation, Department of Sociology, McGill University, Montreal, QC.

Ryan, Charlotte, Kevin M. Carragee and William Meinhofer

2001 "Theory into Practice: Framing, the News Media, and Collective Action." Journal of Broadcasting \& Electronic Media 45(1): 175-82.

Salisbury, Richard F.

1986 A Homeland for the Cree: Regional Development in James Bay, 1971-1981. Kingston, Ont.: McGill-Queen's University Press.

Sanderson, Frances and Heather Howard-Bobiwash

1997 The Meeting Place: Aboriginal Life in Toronto. Toronto: Native Canadian Centre of Toronto. 
What Causes Canadian Aboriginal Protest? 233

Sawyer, Suzana

1997 "The 1992 Indian Mobilization in Lowland Ecuador." Latin American Perspectives 24(3):65-82.

Sewell, William

1996 "Historical Events as Transformations of Structures: Inventing Revolution at the Bastille." Theory \& Society 25(6): 841-881.

Smith, Jackie, John D. McCarthy, Clark McPhail and Boguslaw Augustyn

2001 "From Protest to Agenda Building: Description Bias in Media Coverage of Protest Events in Washington, D.C..” Social Forces 79(4): 1397-1423.

Soule, Sarah A., Doug McAdam, John D. McCarthy and Yang Su

1999 "Protest Events: Cause or Consequence of State Action? The US Women's Movement and Federal Congressional Activities, 1956-1979." Mobilization 4(2): 239-256.

Staggenborg, Suzanne

1996 "The Survival of the Women's Movement: Turnover and Continuity in Bloomington, Indiana." Mobilization 1(2): 143-158.

Swank, Eric

2000 "In Newspapers We Trust? Assessing the Credibility of News Sources That Cover Protest Campaigns." Research in Social Movements, Conflicts \& Change 22:27-52.

Tarrow, Sidney

1988 Power in Movement: Social Movements and Contentious Politics. New York: Cambridge University Press.

1996 "The People's Two Rhythms: Charles Tilly and the Study of Contentious Politics. A review article." Comparative Studies in Society and History 38(3): 586-600.

Tennant, Paul

1990. Aboriginal Peoples and Politics: The Indian Land Question in British Columbia, 1849-1989. Vancouver: University of British Columbia Press.

Turner, Ralph H. and Lewis M. Killian

1987 Collective Behavior. Englewood Cliffs, N.J.: Prentice-Hall.

Van Cott, Dona Lee

2003 "Andean Indigenous Movements and Constitutional Transformation: Venezuela in Comparative Perspective." Latin American Perspective 30(1): 49-69.

VanWynsberghe, Robert

2000 "Sustainability in Proximity to Industry: The Case of Critical Events in Walpole Island." American Indian Culture and Research Journal 24(1): 99-128.

2001 "The "Unfinished Story": Narratively Analyzing Collective Action Frames in Social Movements." Qualitative Inquiry 7(6): 733-744.

Vickers, Jill, Pauline Rankin and Christine Appelle

1993 Politics as if Women Mattered: A Political Analysis of the National Action Committee on the Status of Women. Toronto: University of Toronto Press.

Wilkes, Rima

2004 "First Nation Politics: Deprivation, Resources, and Participation in Collective Action." Sociological Inquiry 74(4): 570-589.

Young, Scott

1969 "A Strange Feeling at the Centre of Indian Discontent." Globe and Mail, Pp. 7, July 11 ${ }^{\text {th }}$, Toronto. 
234 Canadian Journal of Sociology

Zald, Mayer N. and Roberta Ash

1966 "Social Movement Organizations: Growth, Decay and Change." Social Forces 44(3): $327-341$.

Zald, Mayer N. and John D. McCarthy

1980 "Social Movement Industries: Competition and Cooperation among Movement Organizations." Research in Social Movements, Conflicts \& Change 3:1-20. 